\title{
EKSTIRPASI LIPOMA LIDAH DENGAN PENDEKATAN MANDIBULOTOMI
}

\author{
Olivia C. P. Pelealu
}

\author{
Bagian Telinga Hidung Tenggorokan-Bedah Kepala Leher \\ Fakultas Kedokteran Universitas Sam Ratulangi Manado \\ Email: liv_dr@yahoo.com
}

\begin{abstract}
Lipoma is rarely found in the oral cavity. Actually, lipoma is a benign tumor but it will create an operational procedure problem if its size is big and it grows in a difficult location. This tumor is usually found at the age of $40-60$ years, more frequently in men, but the same for all races. Clinically, lipoma occurs as a mass with a smooth surface, yellowish to orange in color, and painless. The diagnosis of a lipoma is confirmed by using a CT scan that shows an irregular globular radioluscent mass with a clear border that seperates it from the surrounding tissues. The definite diagnosis should be based on a fine needle aspiration biopsy (FNAB) and a pathological examination. The management of an oral cavity lipoma is through an operation. We reported a case of a lipoma on the right side of the tongue of a 56-year-old male. The tumor was extirpated with a mandibulotomy approach, in which the mandible is cut to widen the operation field without removing the mandible bone.
\end{abstract}

Keywords: lipoma, tongue, mandibulotomy, extirpation.

\begin{abstract}
Abstrak: Lipoma merupakan tumor yang jarang terjadi dalam kavum oris. Lipoma merupakan tumor jinak namun akan menimbulkan masalah bila berukuran besar dan tumbuh di lokasi yang sulit untuk dilakukan operasi. Tumor ini sering ditemukan pada usia 40-60 tahun, lebih sering pada laki-laki, dan sama untuk semua ras. Secara klinis lipoma tampak sebagai massa dengan permukaan licin, berwarna kekuningan sampai jingga, dan tidak nyeri. Diagnosis untuk lipoma dilakukan dengan $C T$ scan yang memperlihatkan massa ireguler globuler, radiolusen, dan ireguler, serta berbatas jelas dari jaringan sekitarnya. Diagnosis pasti ditegakkan dengan fine needle aspiration biopsy (FNAB) dan pemeriksaan patologi. Penanganan lipoma dalam kavum oris yaitu dengan operasi. Kami melaporkan kasus seorang laki-laki berusia 56 tahun dengan lipoma lidah. Tumor tersebut diekstirpasi dengan pendekatan mandibulotomi, dimana mandibula dipotong untuk meluaskan lapangan pandang operasi tanpa mengangkat tulang mandibula.
\end{abstract}

Kata kunci: lipoma, lidah, mandibulotomi, ekstirpasi.

Lipoma jarang ditemukan dalam kavum oris, lebih banyak pada jaringan subkutan daerah leher. ${ }^{1,2}$ Tumor ini bersifat jinak dengan pertumbuhan lambat, dan terdiri dari sel-sel lemak matur, jaringan ikat kolagen, dan pembuluh darah kecil yang terbungkus dalam simpai. ${ }^{1,3,6}$ Lipoma dengan jaringan ikat berbatas jelas disebut fibrolipoma. ${ }^{1}$ Secara histologik sel lemak lipoma sama dengan sel lemak normal tetapi berbeda secara metabolik. Lipoma kavum oris bisa timbul pada lokasi yang bervariasi seperti lidah, dasar mulut, bukalis, ginggiva, dan mukobukalis dari bibir. ${ }^{1}$ Umumnya lipoma merupakan tumor soliter, bulat, dan permukaan licin, tapi bisa juga multipel bila berlobi. ${ }^{4}$ Secara klinis lipoma berupa tumor dengan epitelium tipis, pada permukaan tampak pembuluh darah superfisial, teraba licin, berwarna kekuningan, dan tidak nyeri. ' Umumnya pasien lipoma memeriksakan diri bila 
ukuran tumor telah besar, menimbulkan masalah kosmetik, atau terjadi komplikasi oleh karena letak anatomisnya. ${ }^{4}$ Insidens lipoma jarang pada usia dekade kedua kehidupan; biasanya muncul saat lemak mulai terakumulasi dalam tubuh pada individu dengan pola hidup kurang aktif (sedentary), yaitu pada usia 40-60 tahun. ${ }^{4-6}$

Secara statistik lipoma lebih sering terjadi pada laki-laki tapi perbedaan insidens pada berbagai ras tidak ditemukan. ${ }^{4}$ Pemeriksaan yang paling membantu untuk diagnosis lipoma yaitu pemeriksaan radiologik. Lipoma tampak sebagai gambaran massa globular radiolusen berbatas jelas dari jaringan sekitarnya. Pada CT scan lipoma tampak sebagai lemak subkutan, densitasnya lebih uniform dari pada gambaran liposarkoma. ${ }^{4}$ Ukuran diameter lipoma bervariasi dari beberapa milimeter sampai 5 $\mathrm{cm}$, jarang $>10 \mathrm{~cm}^{4,6}$ Lipoma biasanya berwarna kuning pucat sampai jingga, berbentuk lobus yang ireguler dengan permukaan licin seperti berminyak. ${ }^{4}$ Penatalaksanaan lipoma dilakukan secara operatif yaitu dengan ekstirpasi. ${ }^{1}$

\section{LAPORAN KASUS}

Seorang laki-laki berusia 56 tahun, berasal dari Jombang, datang pertama kali ke poliklinik onkologi Bagian THT RSU Dr. Soetomo Surabaya dengan keluhan utama adanya benjolan di bagian bawah lidah sejak satu tahun lalu. Awalnya, benjolan ini kecil kemudian semakin membesar, tetapi tidak terasa nyeri. Berbicara agak sulit dan suara tidak jelas, tetapi makan minum tidak terganggu. Tidak dijumpai keluhan parau dan sesak, serta keluhan telinga dan hidung; juga tidak dijumpai riwayat trauma di daerah benjolan.

Pada pemeriksaan fisik keadaan umum pasien cukup dan kesadaran kompos mentis. Pemeriksaan telinga dan hidung tidak memperlihatkan kelainan. Pada inspeksi, di bagian kanan bawah lidah tampak benjolan submukosa berbentuk bulat, berdiameter $8 \mathrm{~cm}$, dan terdapat pelebaran pembuluh darah; tidak ditemukan ulkus. Pergerakan lidah terbatas (Gambar 1). Pada pal- pasi didapatkan benjolan dengan konsistensi padat dan tidak nyeri tekan. Pada daerah submental teraba benjolan yang lunak dan kenyal.

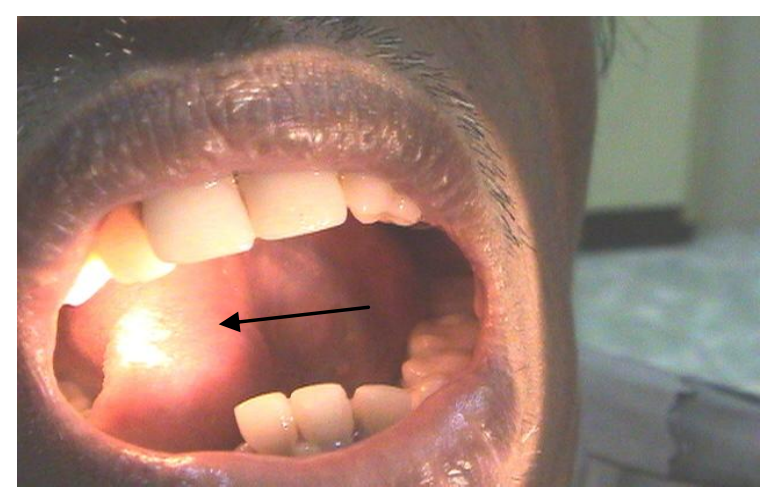

Gambar 1. Lipoma pada bagian kanan lidah pasien (anak panah).

Hasil FNAB dari benjolan tersebut yaitu fibrolipoma. Pemeriksaan $C T$ scan menunjukkan massa berdensitas lemak yang mendesak daerah orofaring dan trakea (Gambar 2). Padan pungsi yang dilakukan di berapa tempat dari benjolan tidak didapatkan cairan maupun nanah. Penanganan untuk pasien ini ialah ekstirpasi fibrolipoma lidah dengan pendekatan mandibulotomi. Operasi dilakukan tiga bulan setelah pemeriksaan pertama. Untuk anestesi, dilakukan intubasi dengan pipa orotrakea tapi tidak berhasil sehingga intubasi dilakukan melalui trakeotomi. Daerah insisi digambar dengan metilen biru dan vermilion bibir ditandai secara horizontal.

\section{Teknik operasi yang dilakukan}

Insisi vertikal dilakukan pada garis tengah bibir bawah melewati dagu sampai batas mandibula kemudian diteruskan ke daerah submandibula kanan (Gambar 3A). Insisi diperdalam untuk memisahkan bibir ke lateral. Pada bagian mandibula, insisi diteruskan sampai ke periosteum, kemudian dibuat flap. Pengeboran dilakukan pada dua tempat di mandibula untuk pemasangan plat fiksasi pasca operasi (Gambar 3B). Mandibulotomi dilakukan vertikal di bagian tengah dengan gergaji gigli (Gambar 
4A). Tulang mandibula diretraksi ke lateral, dilakukan insisi mukosa dasar mulut dengan menyisakan 5-8 milimeter untuk penjahitan mukosa. Duktus kelenjar submandila dipisahkan, nervus lingualis diidentifikasi, dan tumor terlihat dengan jelas (Gambar 4B). Lidah dipegang lalu insisi dilakukan dengan kauter untuk mengangkat tumor. Tumor dipisahkan dari jaringan lidah kemudian diangkat secara in toto. Perdarahan dirawat dengan kauter. Otot lidah yang tersisa dijahit dari posterior ke anterior, diteruskan dengan penjahitan mukosa lidah. Otot dasar mulut dijahit sampai defek tertutup. Mandibula dikembalikan ke posisi semula, bagian tengahnya dipasang plat dengan sekrup pada kedua sisi, dan bagian bawahnya difiksasi dengan kawat (Gambar 5A). Pemasangan vaccum drain dilakukan. Mukosa bibir, dagu, dan submandibula dijahit lapis demi lapis (Gambar 5B). Vermilion bibir dipertemukan pada kedua sisinya dan dijahit tiga lapis. Pemasangan pipa nasogastrik dilakukan sebelum operasi selesai. Tumor yang diangkat secara berukuran 11x8x6 cm, berwarna kuning pucat, dan permukaan licin seperti berminyak dengan konsistensi padat (Gambar 6).
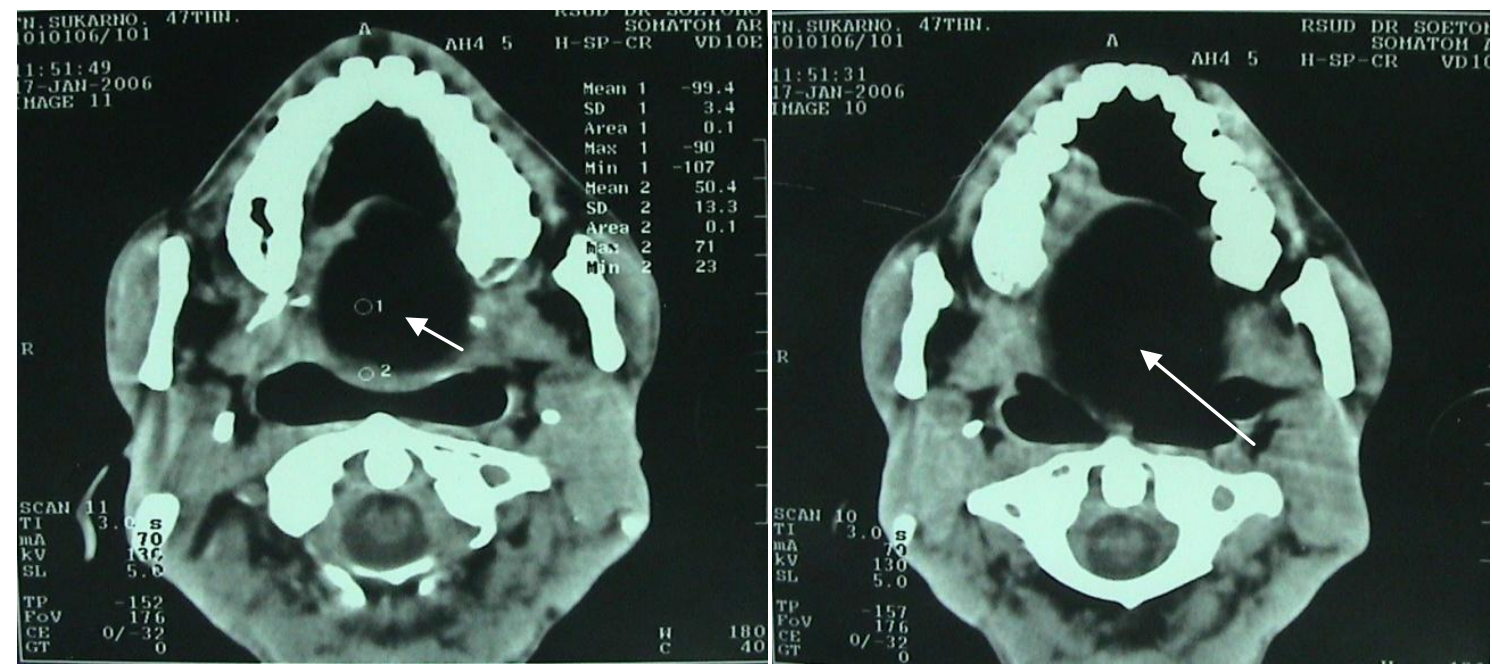

Gambar 2. Hasil CT scan menunjukkan massa berdensitas lemak pada lidah mendesak daerah orofaring dan trakea (anak panah).
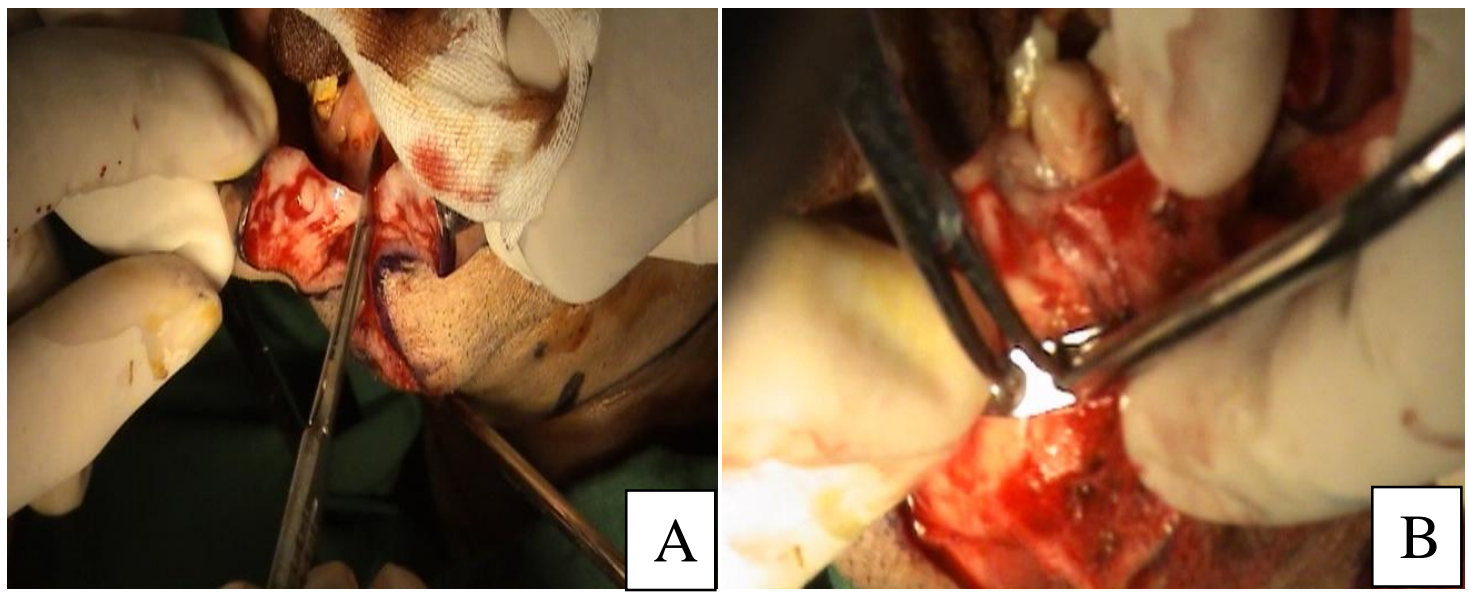

Gambar 3. A, Saat dilakukan pembelahan bibir. B, Pengeboran untuk pemasangan plat pada tulang mandibular. 

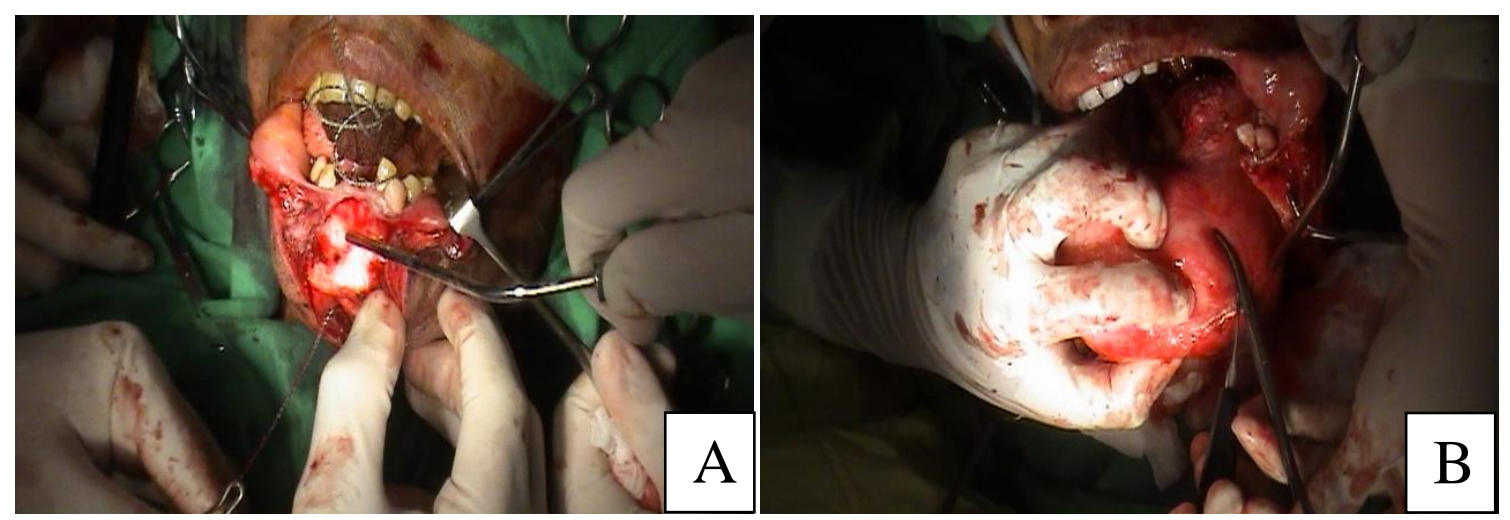

Gambar 4. A, Saat tulang mandibula digergaji dengan gigli. B, Setelah tulang mandibula dipisahkan, tumor lidah dapat tampak dengan jelas.
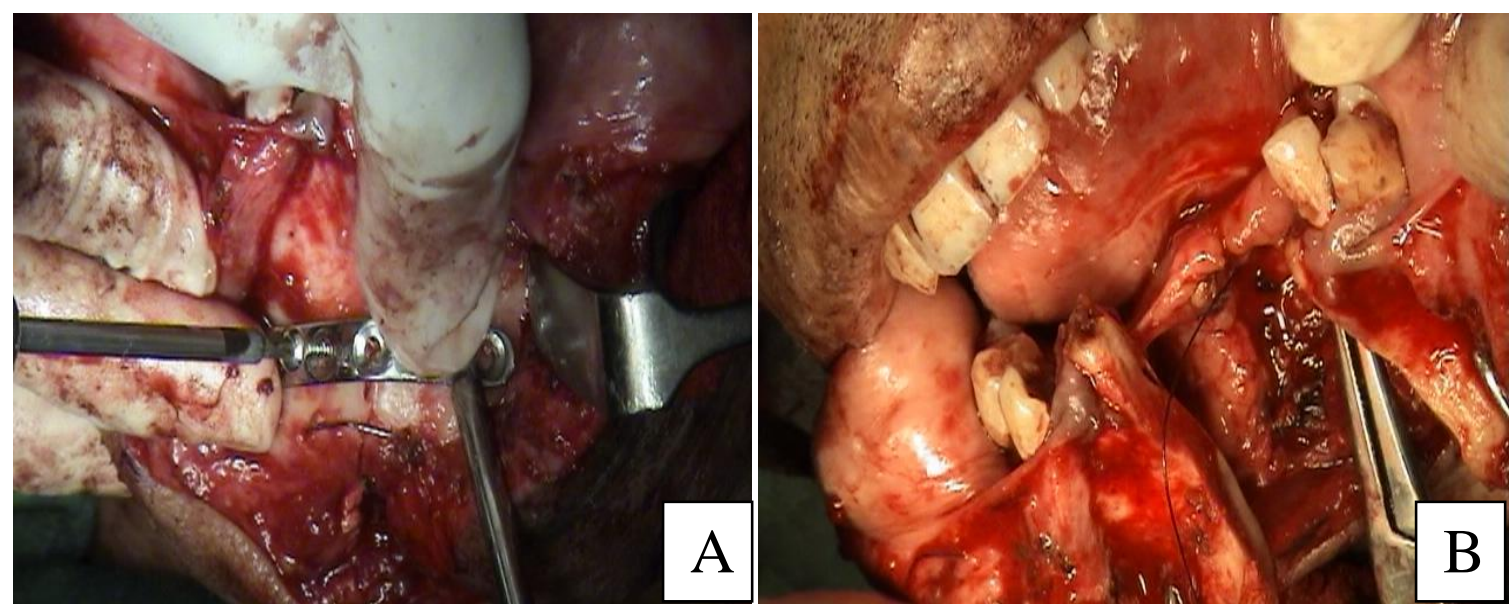

Gambar 5. A, Tulang mandibula disatukan kembali dengan plat dan kawat. B, Luka operasi dijahit lapis demi lapis.

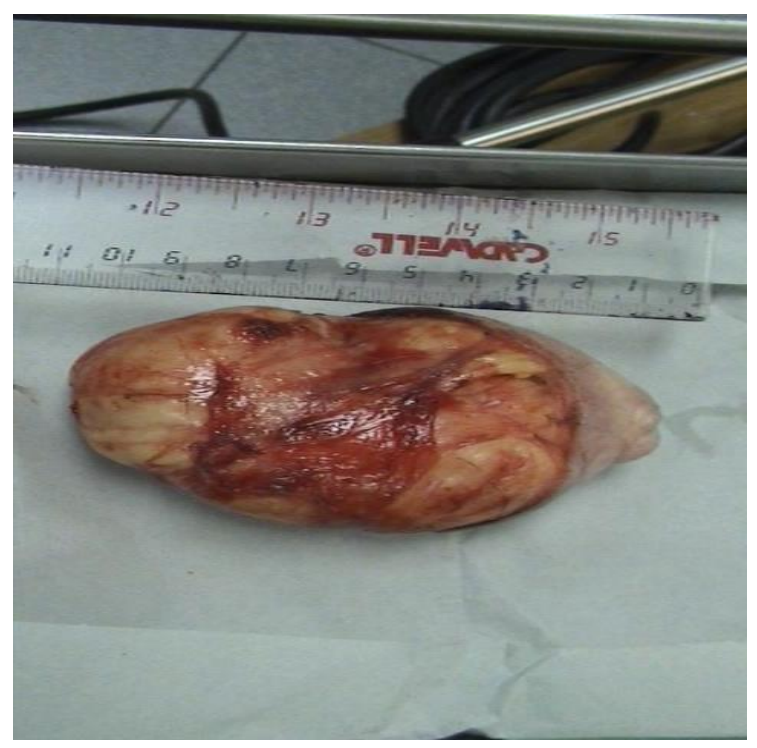

Gambar 6. Tumor yang diekstirpasi berukuran $11 \times 8 \times 6 \mathrm{~cm}$, berwarna kuning pucat, permukaan licin seperti berminyak dengan konsistensi padat.
Pengobatan pasca operasi yang diberikan yaitu seftriakson $1 \times 2$ gram, deksametason 3x1 ampul, asam traneksamat 3x1 ampul, vitamin $\mathrm{A}$, vitamin $\mathrm{C}$, obat kumur yang mengandung antibiotik dan perhidrol $1 \%$, dan mukolitik. Pasien makan dan minum melalui pipa makanan nasogastrik. Perawatan trakeotomi dilakukan dengan suction nebulizer secara periodik dan perawatan anak kanul yang baik. Perawatan luka jahitan operasi menggunakan salep gentamisin dan ditutup dengan kasa steril. Vaccum drain dimonitor sampai produksinya minimal, dan drain dilepaskan setelah tiga hari.

Pada saat follow-up, luka jahitan kering, tidak ada kebocoran dari duktus kelenjar submandibular pada daerah mukosa kavum oris. Lidah masih terlihat 
edema. Satu minggu setelah operasi lidah masih tampak edema minimal. Pasien dituntun untuk bernapas biasa melalui hidung sambil dilakukan penutupan kanul trakea. Sehari setelah pasien bernapas biasa, dilakukan dekanulasi dan pipa nasogastrik dikeluarkan. Sekrup dan kawat yang dipasang untuk fiksasi tulang mandibula tetap dipertahankan agar tidak terjadi dislokasi tulang mandibula. Pasien dipulangkan dan dipesan untuk kontrol lanjut ke Poliklinik Onkologi Bagian THT-KL.

Saat pasien kontrol ke Poliklinik Onkologi THT-KL hari ke-21 pasca operasi, luka operasi telah kering dan luka bekas dekanulasi sudah menutup. Lidah pasien tidak tampak edema lagi dan telah kembali ke bentuk semula. Pasien bisa berbicara dengan normal dengan kualitas suara yang baik. Hasil pemeriksaan histopatologik pasca operasi memperlihatkan gambaran suatu lipoma.

\section{BAHASAN}

Kami melaporkan kasus seorang lakilaki berusia 56 tahun dengan lipoma rongga mulut di sebelah kanan lidah. Hal ini sesuai dengan acuan pustaka yang mengemukakan lipoma biasanya terjadi pada usia 40-60 tahun, lebih sering pada laki-laki, dan tidak dipengaruhi oleh ras. ${ }^{4}$ Diagnosis lipoma pada pasien ini berdasarkan anamnesis yaitu benjolan membesar secara lambat sejak sekitar satu tahun lalu, yang menyebabkan gangguan kosmetik dan kesulitan berbicara karena ukuran tumor yang besar. Acuan pustaka mengemukakan bahwa pertumbuhan lipoma lambat dan biasanya pasien datang memeriksakan diri bila ukuran tumor telah besar, menimbulkan masalah kosmetik, atau setelah terjadi komplikasi oleh karena letak anatomisnya, ${ }^{1,4}$ yang sesuai dengan kasus ini. Pada pemeriksaan lokal ditemukan tumor submukosa yang berdiameter $8 \mathrm{~cm}$, berbentuk bulat, licin, soliter, dan berkonsistensi padat, dengan pelebaran pembuluh darah pada permukaan tumor, yang sesuai dengan gambaran klinis lipoma pada pustaka. ${ }^{1,4}$ Pada pungsi tidak ditemukan cairan atau nanah, yang menun- jukkan bahwa tumor ini terdiri dari jaringan padat. Acuan pustaka menyebutkan bahwa lipoma terdiri dari sel-sel lemak dewasa, dan tidak mengandung cairan. ${ }^{1}$ Diagnosis pasti dari tumor ini yaitu dengan pemeriksaan FNAB yang memperlihatkan gambaran suatu fibrolipoma. Pemeriksaan penunjang lainnya ialah $C T$ scan dengan hasil adanya massa berdensitas lemak pada lidah yang mendesak daerah orofaring dan trakea. Pemeriksaan $C T$ scan sesuai dengan acuan pustaka yang menyebutkan pemeriksaan penunjang yang paling membantu untuk diagnosis lipoma yakni pemeriksaan radiologik. ${ }^{4}$

Penanganan pasien ini yaitu ekstirpasi fibrolipoma lidah dengan pendekatan mandibulotomi. Mandibulotomi adalah pemotongan tulang mandibula untuk menyingkapkan tumor tanpa mengambil bagian tulang, kemudian mandibula dipertemukan kembali setelah tumor diekstirpasi. ${ }^{7}$ Trakeotomi dilakukan sebelum ekstirpasi tumor. Pendekatan mandibulotomi bertujuan untuk dapat menyingkapkan tumor dengan lebih baik, sedangkan trakeotomi dilakukan untuk persiapan pasca operasi untuk mengantisipasi terjadinya perdarahan dan sesak akibat edema jaringan lidah yang hebat. Acuan pustaka menyebutkan bahwa pendekatan mandibulotomi dilakukan untuk memfasilitasi penyingkapan tumor, ekstirpasi tumor, rekonstruksi tumor serta lesi pada kavum oris, orofaring, dan ruang parafaring. ${ }^{8,9}$ Trakeotomi dilakukan dengan anestesi lokal sebelum tindakan anestesi umum karena sempitnya daerah orofaring untuk memasukan pipa intubasi orotrakea. Intubasi tidak dimasukkan melalui kavum oris tetapi melalui stoma trakea. Acuan pustaka juga mengemukakan manfaat trakeotomi yaitu untuk menjamin kelancaran jalan napas pasca operasi. ${ }^{10}$

Teknik operasi yang dilakukan sesuai dengan pendekatan mandibulotomi dalam pustaka acuan. Insisi dilakukan vertikal pada garis tengah bibir bawah, melewati dagu sampai batas mandibula kemudian diteruskan ke daerah submandibular kiri. Insisi diperdalam, kemudian bibir dipisahkan ke lateral. Pada bagian mandibula, 
insisi diteruskan sampai ke periosteum, kemudian dibuat flap. Pengeboran dilakukan pada dua tempat di kedua bagian mandibula untuk pemasangan plat pasca operasi. Pengeboran ini dilakukan untuk kepentingan fiksasi mandibula pasca operasi dengan plat, sekrup, dan kawat. Mandibulotomi dilakukan vertikal di bagian tengah dengan gergaji gigli. Acuan pustaka mengemukakan mandibulotomi dilakukan berbentuk anak tangga dengan tujuan mempertahankan posisi tulang mandibula setelah operasi agar tidak mudah terjadi dislokasi. ${ }^{10}$ Pada pasien ini dilakukan mandibulotomi secara vertikal karena penggunaan gergaji gigli tidak memungkinkan untuk membuat bentuk anak tangga. Keuntungan melakukan mandibulotomi di bagian tengah yaitu mengurangi perdarahan dan menghindari terpotongnya nervus fasialis ramus marginalis mandibularis dan nervus mentalis. ${ }^{12}$ Mandibulotomi tidak selalu dilakukan pada garis tengah tulang, tetapi di antara kedua foramen mentalis; hal ini dapat memaksimalkan aliran darah pada tulang mandibula saat penyembuhan luka pasca operasi. ${ }^{10}$

Tulang mandibula diretraksi ke lateral, dilakukan insisi mukosa dasar mulut dengan menyisakan 5-8 milimeter untuk penjahitan mukosa, dilakukan pemisahan duktus kelenjar submandibular, dan diidentifikasi nervus lingualis. Acuan pustaka juga mengemukakan insisi mukosa yang dilakukan lebih ke lateral tetapi dengan menyisakan 5-8 mm untuk kepentingan penjahitan dan penutupan luka setelah ekstirpasi tumor. ${ }^{11}$ Identifikasi duktus kelenjar submandibula dilakukan agar tidak terjadi kebocoran pasca operasi dan identifikasi n. lingualis agar tidak terjadi kerusakan pada saraf tersebut.

Pada saat tumor telah tersingkap, lidah dipegang dan kemudian dilakukan insisi dengan kauter untuk mengangkat tumor. Keseluruhan tumor dipisahkan dari jaringan lidah, kemudian diangkat secara in toto. Perdarahan dirawat dengan kauter. Insisi dilakukan dengan kauter untuk mengurangi perdarahan. Otot lidah yang tersisa dijahit dari posterior ke anterior dengan dua lapis jahitan, diteruskan dengan penjahitan mukosa lidah. Hal ini sesuai dengan acuan pustaka yaitu penjahitan otot lidah dilakukan sekurang-kurangnya dengan dua lapis jahitan dari arah posterior ke anterior. ${ }^{11}$ Otot dasar mulut dijahit sampai defek tertutup. Mandibula dikembalikan ke posisi semula dan dipasang plat dengan sekrup pada kedua sisi mandibula bagian tengah dan bagian bawah difiksasi dengan kawat. Sesuai dengan acuan pustaka bahwa mandibula dikembalikan pada posisi anatomis semula, dan dipasang plat dengan dua sekrup pada masing-masing sisi mandibula. ${ }^{11}$ Pada operasi ini ditambahkan dengan kawat di bagian bawah dengan tujuan memperkuat fiksasi mandibula. Pemasangan vaccum drain dilakukan untuk mengeluarkan produksi cairan. Mukosa dari bibir, dagu, dan submandibula dijahit lapis demi lapis. Pada waktu menjahit vermilion bibir harus dipertemukan pada kedua sisinya. Penjahitan dilakukan tiga lapis sesuai dengan acuan pustaka, dimulai dengan penutupan otot orbikularis oris, selanjutnya mukosa dan kulit. ${ }^{10}$

Pemasangan pipa nasogastrik pasca operasi dilakukan agar penyembuhan luka operasi mukosa oral dan lidah tidak terganggu oleh makanan. Selain itu, keadaan pasien tidak memungkinkan untuk mengunyah dan menelan makanan akibat adanya luka operasi pada mukosa kavum oris dan lidah. Pergerakan pada saat mengunyah juga bisa mengganggu penyembuhan pada tulang mandibula. Kebocoran pada duktus kelenjar submandibular akan memperlambat proses penyembuhan luka operasi. Acuan pustaka menyebutkan pemakaian pipa nasogastrik bermanfaat untuk penyembuhan luka yang baik tanpa kontaminasi dari makanan. 10,11

Pengobatan yang diberikan pasca operasi yaitu antibiotik parenteral seftriakson $1 \mathrm{x} 2 \mathrm{~g}$ dan obat kumur yang mengandung antibiotik dan perhidrol 1\%, yang sesuai dengan acuan pustaka yang menyebutkan pemberian antibiotik parenteral dan perawatan kavum oris dengan obat kumur yang mengandung antibiotik. ${ }^{10}$

Perawatan luka jahitan operasi meng- 
gunakan salep gentamisin dan ditutup dengan kasa steril, yang bertujuan agar luka operasi cepat kering dan tidak terkontaminasi kuman dari kulit sekitar sehingga tidak terjadi infeksi nosokomial. Vaccum drain yang dipasang dimonitor. Setelah tiga hari produksi sekret telah minimal, dan drain dilepaskan, yang sesuai dengan acuan pustaka yang menyebutkan pelepasan drain dilakukan bila produksinya kurang dari 15 ml per hari. ${ }^{10}$

Dekanulasi dilakukan saat jalan napas pasien tidak terganggu oleh adanya edema lidah dan jaringan sekitarnya, yaitu kirakira seminggu pasca operasi. Pada pasien ini dicoba dulu dengan menutup kanul trakea selama 24 jam, sehingga pasien dapat bernapas biasa, kemudian dilakukan dekanulasi. Pengeluaran pipa nasogastrik dilakukan setelah dekanulasi. Pipa nasogastrik dipertahankan sampai luka pada kavum oris sudah sembuh dan menutup serta setelah dilakukan dekanulasi. Sebelum pasien makan per oral, dilakukan dekanulasi dulu untuk memaksimalkan proteksi dari paru dan efisiensi fungsi batuk. ${ }^{10}$ Pasien diizinkan pulang setelah bisa makan biasa per oral dengan baik. Acuan pustaka menganjurkan untuk konsumsi makanan cair dan lunak pada saat mulai makan per oral; makanan keras tidak dianjurkan sampai minggu keenam pasca operasi. ${ }^{10}$

Makroskopik tumor berukuran 11x8x6 $\mathrm{cm}$, berwarna kuning pucat, permukaan licin seperti berminyak dengan konsistensi padat. Menurut acuan pustaka, lipoma berukuran $>10 \mathrm{~cm}$ jarang ditemukan, biasanya berwarna kuning pucat sampai jingga, berbentuk lobus ireguler dengan permukaan licin seperti berminyak. ${ }^{4}$

Pada saat pasien datang kontrol, luka operasi diperiksa apakah sudah tampak tanda-tanda penyembuhan tulang mandibula. Bila tidak terjadi penyatuan tulang mandibula, maka akan terasa nyeri di daerah tersebut. Material berupa plat, sekrup, dan kawat yang dipakai untuk fiksasi tulang mandibula sebaiknya dikeluarkan pada saat penyembuhan sudah lengkap. Setelah dua bulan pasca operasi, bisa dilakukan bedah minor untuk mengeluarkan material tersebut. ${ }^{11}$

\section{SIMPULAN}

Lipoma termasuk tumor jinak yang secara klinis berbentuk bulat, permukaan licin seperti berminyak, berwarna kekuningan, dan berkapsul. Secara histologik, lipoma tersusun oleh sel-sel lemak dewasa; bila terdapat jaringan ikat yang nyata disebut fibrolipoma.

Kasus ini didiagnosis lipoma lidah melalui anamnesis. Hasil pemeriksaan FNAB memperlihatkan suatu fibrolipoma, dan $C T$ scan menunjukkan massa berdensitas lemak yang mendesak daerah orofaring dan trakea. Ekstirpasi tumor dilakukan dengan pendekatan mandibulotomi untuk menyingkapkan tumor dengan lebih baik, didahului oleh trakeotomi mengantisipasi terjadinya perdarahan dan sesak akibat edema jaringan lidah yang hebat pasca operasi. Tumor yang diekstirpasi memperlihatkan gambaran suatu lipoma lidah yang besar $(11 \times 8 \times 6 \mathrm{~cm})$.

\section{DAFTAR PUSTAKA}

1. Shafer WG, Hine MK, Levy BM. A Textbook of Oral Pathology (Fourth Edition). Taipei: University Book Publishing Company, 1983.

2. Rosai J. Rosai and Ackerman's Surgical Pathology Volume 1 (Tenth Edition). Edinburgh: Elsevier Mosby, 2011.

3. Brooks SJ. Disorders of soft tissue. In: Mills SE, editor. Sternberg's Diagnosis Surgical Pathology Volume 1 (Fourth Edition). Philadelphia: Lippincott Williams and Wilkins, 2004; p. 174-5.

4. Weiss SW, Goldbum JR. Enzinger and Weiss's Soft Tissue Tumors (Fourth Edition). Missouri: Mosby Inc, 2001; p. 571-85.

5. Rosenberg AE. Bones, joints, and soft tissue tumors. In: Kumar V, Abbas AK, Fausto N, Aster JC, editors. Robbins and Cotran Pathologic Basis of Diseases (Eighth Edition). Philadelphia, Saunders Elsevier, 2010: 1249-50.

6. Cawson RA, Odell EW. Soft tissue (mesenchymal) neoplasms. Cawson's Essentials of Oral Pathology and Oral Medicine (Eighth Edition). Edinburgh: 
Churchill Livingstone Elsevier, 2008.

7. Eibling DE. Composite resection. In: Myers EN, editor. Operative Otolaryngology Head and Neck Surgery Volume 1. Philadelphia: WB Saunders Company, 1997: 309-26.

8. Biller HF, Shugar JMA, Krespi YP. A new technique for wide-field exposure of the base of the skull. Arch Otolaryngol. 1981;107: 698-702.

9. Beecroft WA, Sako K, Razack MS, Shedd DP. Mandible preservation in the treatment of cancer of the floor of the mouth. J surg oncol. 1982;19:171-5.

10. Johnson JT. Mandible-splitting approaches. In: Myers EN, editor. Operative Otolaryngology Head and Neck Surgery Volume 1. Philadelphia: WB Saunders Company, 1997: 294303.

11. Johnson JT. Mandibulotomy and oral cavity resection. In: Myers EN, editor. Operative Otolaryngology Head and Neck Surgery Volume 1. Philadelphia: WB Saunders Company, 1997: 304-8.

12. Stiernberg CM. Oropharyngeal cancer. In: Bailey BJ, editor. Head and Neck Surgery-Otolaryngology Volume 2. Philadelphia: JB Lippincott Company, 1993: 1274-85. 